\title{
Efektivitas Teknologi Pembelajaran Dalam Menumbuhkan Minat Siswa Belajar Pendidikan Agama Islam (PAI)
}

\author{
Eva Dwi Kumala Sari \\ STIT Al Marhalah Al Ulya Bekasi \\ Email: kumalasarieva@gmail.com
}

\begin{abstract}
Learning technology is one of the important components in supporting the learning process. So that the learning process becomes more conducive. Likewise, the teaching and learning process in the field of Islamic Religious Education studies, learning activities in that field can be applied with learning technology in order to foster student interest in learning the field of Islamic Religious Education studies.

This study aims to obtain empirical data on the Effectiveness of Learning Technology in Growing Student Interest in Learning Islamic Religious Education. So that it can obtain the effectiveness caused in the process of teaching and learning students who use technology and who do not use learning technology. This research was conducted on students of class VIII at SDI Tahta Syajar Bekasi.

Writing this article uses several data collection techniques including observation, interviews, literature studies, and questionnaires. While the method used is descriptive quantitative method, with sampling using random sampling, about $20 \%$ consisting of 86 students from the existing population. Then start by testing different respondent instruments. After that spread the test that has been tested, the variables examined are the Effectiveness of Learning Technology as the independent variable, and the interest of students learning PAI as the dependent variable. Data analysis using Product Moment correlation. The results of the calculation of the Effectiveness of Learning Technology in the mean empirical score of 105.69> mean theoretical score of 72.50 thus the reality of the results of the Learning Technology Effectiveness score is categorized high. and the mean empirical score on PAI learning interest in can be 129.90> 80 from the mean theoretical score so the reality score of Islamic Education Learning Interest Interest is categorized high.

Whereas, for the normality test of Learning Technology Effectiveness obtained, Lhitung $=0.072<0.096=$ Ltabelmaka, the null hypothesis is accepted, for the interest in learning PAI, it is obtained Lhitung $=0.048$ $<0.096=$ Ltabelmaka, the null hypothesis is accepted, meaning that both variables are normally distributed. To calculate the product moment correlation coefficient can be calculated $r$ by 0.619 which there is a positive
\end{abstract}


correlation between variable $X$ and $Y$. Continue the $t$-student test because tcount $=7.22>2.00=t(0.975)(86)$, then the hypothesis zero rejected. This means that there is a significant relationship between variable $X$ with variable $Y$. And the results of the calculation of the coefficient of determination of 0.3831 this means that learning technology contributes $38.31 \%$ to the interest in learning PAI, while $61.69 \%$ of other factors .

Keywords: Learning Technology, Interest in Learning PAI.

\section{Pendahuluan}

Pendidikan merupakan faktor penting dalam berlangsungnya kehidupan sebuah bangsa, terutama bangsa Indonesia dimana bangsa kita ialah bangsa yang sedang berkembang, sehingga masih sangat di butuhkan generasi-generasi yang bermutu. Oleh sebab itu, Pendidikan yang berkualitas sangat diperlukan dalam membentuk negara yang maju, karena melalui pendidikan akan timbul generasi-generasi penerus bangsa yang handal baik dari segi intelektualitas, emosional maupun spiritual.

Hal ini Sesuai dengan Peraturan Pemerintah Republik Indonesia (PPRI) Nomor 19 Tahun 2005 tentang Standar Nasional Pendidikan Pasal 26 ayat 4 tentang tujuan pendidikan yang mengatakan untuk mempersiapkan peserta didik menjadi anggota masyarakat yang: 1) berakhlak mulia, 2) memiliki pengetahuan, 3) terampil, 4) mandiri, 5) mampu menemukan, mengembangkan, dan menerapkan ilmu, teknologi, serta seni yang bermanfaat bagi kemanusiaan. Dan tujuan pendidikan ini sudah komprehensif, sebab sudah mencakup ranah afeksi, kognisi, psikomotor, serta di lengkapi dengan kemampuan mandiri, dan faktor yang paling menentukan kehidupan dan kemajuan pendidikan adalah dedikasi, keterampilan, pendidik dan keahlian. ${ }^{1}$

\footnotetext{
1. Made Pidarta, Landasan Kependidikan (Stimulus Ilmu Pendidikan Bercorak Indonesia), (Jakarta: Rineka Cipta, 2009), hlm. 13. 
Kompetensi profesional dimana kita sebagai guru dituntut untuk mengembangkan materi pembelajaran lebih kreatif dan inovatif dari sumbersumber belajar baik berupa buku teks, media cetak, media pembelajaran, nara sumber, maupun lingkungan sekitar hal ini merupakan bagian integral dalam sistem pembelajaran. Agar dapat menarik minat belajar siswa. Karena apabila minat belajar sudah tumbuh maka akan lebih mudah bagi guru untuk mentransfer ilmu kepada para siswa. Untuk itulah guru harus memiliki terobosan dalam memancing minat para siswa seperti menggunakan media berupa teknologi pembelajaran.

Teknologi sendiri merupakan hasil rekayasa manusia yang di cipta dan dikembangkan untuk mengatasi masalah manusia. Di sekolah-sekolah kini terutama di kota-kota besar, teknologi dalam berbagai bentuk dan jenisnya sudah di pergunakan untuk mencapai tujuan belajar.

Pendidikan di masa lalu guru merupakan satu-satunya sumber belajar bagi anak didik. Sehingga proses belajar mengajar masih menggunakan cara yang tradisional, karena penyebaran perangkat teknologi sangat terbatas. Namun saat ini, Teknologi telah menjadi bagian yang integral dalam kehidupan manusia bahkan sudah tidak mampu dielakan dalam dunia pendidikan.

Teknologi pembelajaran merupakan suatu disiplin ilmu terapan, yang berkembang oleh adanya kebutuhan yang mendorong agar kegiatan belajar mengajar berjalan secara efektif dan efisien. Maka dari itu, ada suatu produk yang dikembangkan untuk kepentingan belajar tersebut. Ditengah maraknya berbagai permasalahan belajar yang terus berkembang, kemajuan teknologi informasi dan komunikasi yang berkembang cepat pun mampu menawarkan sejumlah jalan keluar. Sehingga mampu merubah cara berfikir orang dalam mengambil manfaat dari kemajuan teknologi untuk kepentingan belajar. 
Sebelum teknologi komunikasi dan informatika merambah kehidupan manusia, penggunaan peraga dalam bentuk chart dan model merupakan favorit bagi guru dan dosen. Pada era tahun 1980-an , penggunaan media transparasi OHP menjadi trend bagi pengajar dan instruktur pelatihan maupun presenter dalam forum-forum ilmiah seperti seminar, lokal karya, dan sebagainya. Namun itu tidak bertahan lama karena di era tahun 2000-an di awal milenium ketiga muncul trend teknologi yang lebih canggih yang menjadi pilihan bagi tenaga pengajar yaitu multimedia dan media intraktif. ${ }^{2}$

Maka dari itu tenaga pengajar saat ini sangatlah dituntut untuk mampu memanfaatkan teknologi kemudian diaplikasikan dengan model pembelajaran alternatif yang inovatif berbasis teknologi sehingga dapat menarik minat peserta didik dan membantu memecahkan masalah belajar dan pembelajaran. Misalnya pengunaan buku, televisi, siaran radio, komputer dan lain-lain dalam mengupayakan pemanfaatan teknologi untuk pemerataan akses pendidikan serta untuk menunjang peningkatan kualitas proses pembelajaran.

Perkembangan teknologi tidak hanya mempengaruhi pendidikan pada bidang studi umum saja. Tetapi juga berdampak pada bidang studi Pendidikan Agama Islam (PAI) yang tidak lepas dari pengaruh perkembangan pendidikan. Sejauh ini di berbagai jenjang pendidikan mulai dari tingkat Taman Kanak-kanak (TK) sampai keperguruan tinggi baik negeri maupun swasta. Bidang studi PAI merupakan bidang studi yang sangat penting, karena dengan adanya bidang studi PAI siswa diharapakan memiliki kehidupan yang terarah dan menjadi insan kamil sesuai dengan Syari'at yang dibawa oleh Nabi Muhammad SAW dan diperintahkan oleh Allah SWT.

Namun, ironisnya beberapa tahun lalu bidang studi PAI tidak seperti bidang studi umum lain yang banyak diminati oleh siswa dan mendapat

\footnotetext{
${ }^{2}$. Fatah Syukur, Teknologi Pendidikan (Semarang: RaSAIL Media Group. 2008), hlm. x. - 44 -
}

Al Marhalah : Jurnal Pendidikan Islam. Volume. 1, No.2 November 2017 
perhatian khusus dari seluruh perangkat sekolah karena banyaknya bidang studi umum yang diujikan pada Ujian Nasional, bidang studi PAI seakanakan di kesampingkan dan hanya di jadikan pelengkap dalam dunia pendidikan saja.

Tetapi, mulai tahun 2012 ini, Pendidikan Agama Islam masuk Ujian Sekolah Berstandar Nasional (USBN) mulai tingkat SD, SMP, SMA, dan SMK. Bentuk ujian meliputi ujian praktik dan ujian tulis. Peraturan Pemerintah No.55 tahun 2007 tentang Pendidikan Agama dan Pendidikan Keagamaan mengamanatkan bahwa pendidikan agama merupakan tanggungjawab Kementerian Agama sebagaimana yang dinyatakan pada Pasal 3 ayat (1) bahwa setiap satuan pendidikan pada semua jalur, jenis, dan jenjang pendidikan wajib menyelenggarakan pendidikan agama, dan ayat (2) bahwa pengelolaan pendidikan agama dilaksanakan oleh Menteri Agama.

Sejalan dengan itu, Peraturan Menteri Agama RI. No. 16 tahun 2010 tentang Pengelolaan Pendidikan Agama pada sekolah, pada Bab IX Pasal 26 ayat (1) menegaskan bahwa penilaian hasil belajar pendidikan agama meliputi penilaian hasil belajar oleh pendidik, satuan pendidikan dan pemerintah. Selanjutnya ayat 4 menjelaskan bahwa penilaian hasil belajar sebagaimana dimaksud pada ayat (1) dilakukan dalam bentuk ujian yang dilaksanakan secara nasional.

Pendidikan Agama Islam di sekolah mempunyai peran yang strategis dalam pengembangan sistem pendidikan nasional di Indonesia dan peningkatan mutu sumber daya manusia. Oleh karenanya untuk mengetahui mutu pendidikan agama Islam yang dilaksanakan di sekolah secara nasional, maka perlu dilakukan evaluasi yang menyeluruh terhadap hasil pembelajaran peserta didik melalui Ujian Sekolah Berstandar Nasional Pendidikan Agama Islam (USBN PAI). 
Pelaksanaan USBN PAI pada tahun ini diharapkan mengalami peningkatan dalam berbagai hal. Oleh karena itu, pedoman pelaksanaan harus selalu memperhatikan perkembangan dalam ranah-ranah yang berkenaan dengan ujian ini.

Pedoman yang dimaksud adalah sebagaimana Keputusan Direktur Jenderal Pendidikan Islam Nomor: DJ.I/1510/2011 tentang Pelaksanaan Ujian Sekolah Berstandar Nasional (USBN) Mata Pelajaran Pendidikan Agama Islam pada SD, SMP, DAN SMA / SMK TAHUN PELAJARAN $2011 / 2012^{3}$

Namun, keputusan ini tidak sepenuhnya di dukung oleh para tenaga pendidik dan masyarakat. Karena pada pelaksanaannya, pemerintah maupun guru serta peserta didknya tidak siap dalam meng-USBN-kan PAI, berbagai argumen mengiringi pelaksanaan USBN PAI.

Kenyataan ini sangat mempengaruhi minat siswa untuk mempelajari bidang studi PAI yang memiliki jumlah pertemuan kurang lebih hanya satu kali dalam seminggu. Tanggung jawab guru bidang studi PAI terasa semakin berat karena selain harus mencapai target pembelajaran yang ditentukan, guru bidang studi PAI pun harus mampu menanamkan nila-nilai syari'at Islam dalam diri tiap-tiap siswa. Sehingga guru harus kerja ekstra untuk menemukan metode dan media pembelajaran yang cocok dengan materi belajar.Pada keadaan inilah teknologi diharapakan mampu untuk membantu guru bidang studi PAI dalam meningkatkan minat siswa belajar Agama Islam.

Hal yang paling mendukung dalam hal proses belajar mengajar adalah minat. Minat menurut Slameto, memberikan pengertian bahwa minat adalah suatu rasa lebih suka dan rasa keterikatan pada suatu hal atau aktivitas tanpa

\footnotetext{
3. Kementrian Agama RI,“UN / UAMBN / USBN Tahun 2012,” artikel dikses pada 10 September 2012 dari http://mapendakukar.blogspot.com/p/pendataan-un.html - 46 -
}

Al Marhalah : Jurnal Pendidikan Islam. Volume. 1, No.2 November 2017 
ada yang menyuruh. ${ }^{4}$ Adapun menurut Hilgard; yang dikutip oleh Slameto dalam bukunya mengatakan bahwa minat adalah kecenderungan yang tetap untuk memperhatikan dan mengenang beberapa kegiatan. ${ }^{5}$ Sedangkan menurut Alisuf Sabri; mendefinisikan bahwa minat (interest) adalah suatu kecenderungan untuk selalu memperhatikan dan mengingat sesuatu secara terus menerus dan merupakan pola reaksi Individu terhadap lingkungan. ${ }^{6}$

Adapula definisi menurut Crow and Crow; yang dikutip oleh Ramayulis dalam bukunya mengatakan bahwa minat adalah kekuatan pendorong yang menyebabkan individu memberikan perhatian kepada seseorang atau kepada aktivitas-aktivitas tertentu. ${ }^{7}$ Adapula menurut Bimo Walgito yang dikutip oleh Ramayulis dalam bukunya mengatakan bahwa minat adalah suatu keadaan dimana seseorang mempunyai perhatian sesuatu dan disertai dengan keinginan untuk mengetahui dan mempelajari maupun membuktikan lebih lanjut. ${ }^{8}$

Sadirman mendefinisikan bahwa minat adalah suatu kondisi yang terjadi apabila seseorang melihat ciri-ciri atau arti sementara situasi yang dihubungkan dengan keinginan-keinginan atau dengan kebutuhankebutuhannya sendiri. ${ }^{9}$ Dan Muhibbin Syah mendefinisikan minat (Interest) secara sederhana, yaitu kecenderungan dan kegairahan yang tinggi atau keinginan yang besar terhadap sesuatu. ${ }^{10}$

Dari beberapa definisi minat yang telah dikemukakan oleh beberapa tokoh di atas, maka minat adalah Pola reaksi suatu Individu yang memiliki

35. Slameto, Belajar dan Faktor-Faktor yang Mempengaruhinya (Jakarta: Rineka Cipta, 2010), hlm.180

5. Ibid., hlm. 57.

6. Alisuf Sabri, Psikologi Pendidikan Berdasarkan Kurikulum Nasional. (Jakarta : Pedoman Ilmu Jaya, 2010), hlm. 83.

${ }^{38}$. Ramayulis. Ilmu Pendidikan Islam (Jakarta : Kalam Mulia, 2002), hlm. 38.

${ }^{8}$. Ibid., hlm. 38.

9. Sadirman, Interaksi dan Motivasi Belajar Mengajar (Jakarta: Rajawali, 1992), hlm. 76.

${ }^{10}$. Muhibbin Syah, Psikologi Belajar (Jakarta: Raja Grafindo Persada, 2012), hlm. 152.

Al Marhalah : Jurnal Pendidikan Islam. Volume. 1, No. 2 November 2017 
kecenderungan terhadap sesuatu baik berupa situasi, objek maupun aktivitas yang dianggap penting untuk memenuhi kebutuhan dirinya sehingga selalu diingat, diperhatikan, dibayangkan dan diikuti secara terus menerus tanpa merasa terbebani.

Hal yang dapat meningkatkan minat belajar adalah teknologi pembelajaran, teknologi pembelajaran merupakan suatu ilmu terapan yang digunakan untuk mempermudah dan memfasilitasi proses belajar mengajar sehingga berjalan lebih efektif. Teknologi pembelajaran memiliki dua suku kata yang saling melengkapi satu dengan yang lainnya, yaitu kata teknologi dan pembelajaran.

\section{Perumusan Masalah}

Dari pembatasan-pembatasan di atas, maka penulis akan merumuskan masalah sebagai berikut:

1. Apakah terdapat keefektivitasan antara teknologi pembelajaran dengan minat belajar Pendidikan Agama Islam di SDI Tahta Syajar Bekasi?

2. Bagaimana Pengaruh Teknologi Pembelajaran dalam menumbuhkan minat siswa belajar Pendidikan Agama Islam di SDI Tahta Syajar Bekasi?

\section{Metode Penelitian}

Metodologi penelitian yang akan digunakan dalam penelitian ini adalah metode kuantitatif Deskriptif, yaitu suatu metode yang bertujuan untuk mendapatkan data-data yang jelas tentang hal-hal yang berkaitan dengan teknologi pembelajaran dan menumbuhkan minat belajar siswa dalam PAI. Untuk menganalisis data penelitian menggunakan korelasi Product Moment. Sebelum dilakukan korelasi Product Moment maka dilakukan uji normalitas ( uji Liliefors) dan uji homogenitas ( Uji F). 
Efektivitas Teknologi Pembelajaran dalam Menumbuhkan Minat Siswa Belajar Pendidikan Agama Islam (PAI)

\section{Hasil Penelitian}

\section{Frekuensi Kumulatif}

\begin{tabular}{|c|c|c|c|c|c|}
\hline No & Skor & $\mathbf{f}$ & $\begin{array}{c}\text { Titik } \\
\text { Tengah }\end{array}$ & F Relatif & F Kumulatif \\
\hline 1 & $72-81$ & 7 & 76,5 & 8,14 & 8,14 \\
\hline 2 & $82-91$ & 13 & 86,5 & 15,12 & 23,26 \\
\hline 3 & $92-101$ & 19 & 96,5 & 22,09 & 45,35 \\
\hline 4 & $102-111$ & 16 & 106,5 & 18,60 & 63,95 \\
\hline 5 & $112-121$ & 12 & 116,5 & 13,95 & 77,91 \\
\hline 5 & $122-131$ & 10 & 126,5 & 11,63 & 89,53 \\
\hline 6 & $132-142$ & 9 & 136,5 & 10,47 & 100,00 \\
\hline \multicolumn{2}{|c|}{ Jumlah } & $\mathbf{8 6}$ & & $\mathbf{1 0 0 , 0 0}$ & \\
\hline
\end{tabular}

\section{Gambar I}

\section{Grafik Histogram dan Poligon Frekuensi Efektivitas Teknologi}

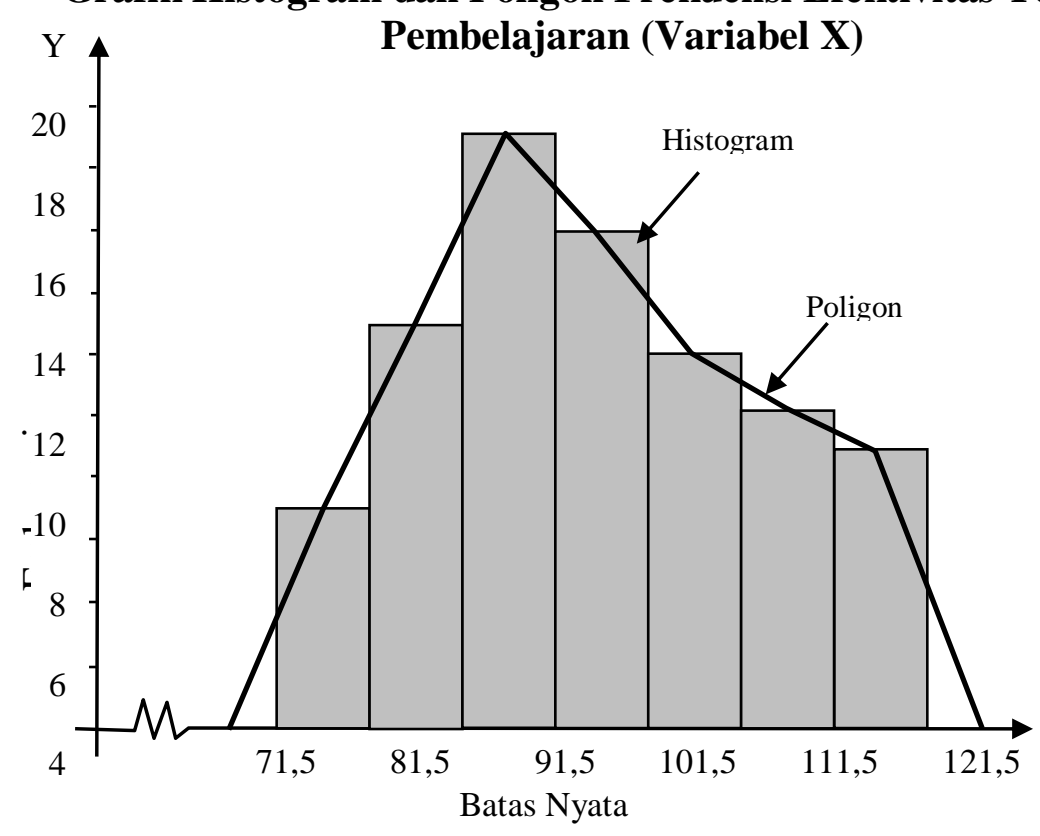


Klasifikasi Skor Efektivitas Teknologi Pembelajaran

\begin{tabular}{|c|c|c|c|c|}
\hline No & Interval Nilai & $\mathbf{f}$ & \% & Interpretasi \\
\hline 1 & $\mathrm{X}>123,29$ & 16 & 18,60 & Tinggi \\
\hline 2 & $88,08-123,29$ & 54 & 62,79 & Cukup \\
\hline 3 & $\mathrm{x}<88,08$ & 16 & 18,60 & Rendah \\
\hline
\end{tabular}

Berdasarkan tabel di atas, diperoleh informasi dan gambaran bahwa skor efektivitas teknologi pembelajaran sebanyak 18,60\% yang memperoleh skor tinggi, $62,79 \%$ memperoleh skor cukup, dan 18,60\% memperoleh skor rendah.

Selanjutnya untuk mengetahui tinggi rendahnya hasil skor efektivitas teknologi pembelajaran siswa dilakukan dengan cara membandingkan rerata (mean) hasil perhitungan (mean empirik) dengan rerata teoritik. Berdasarkan perhitungan rerata sebagaimana dikemukakan di atas menunjukkan bahwa rerata empirik 105,69 > rerata teoritik 72,50 dengan demikian realitas hasil skor efektivitas teknologi pembelajaran di kelas VIII SMP Negeri 4 Bekasi dikategorikan tinggi.

\section{Frekuensi Kumulatif}

\begin{tabular}{|c|c|c|c|c|c|}
\hline No & Skor & F & Titik Tengah & F Relatif & F Kumulatif \\
\hline 1 & $105-111$ & 8 & 108 & 9,30 & 9,30 \\
\hline 2 & $112-118$ & 10 & 115 & 11,63 & 20,93 \\
\hline 3 & $119-125$ & 13 & 122 & 15,12 & 36,05 \\
\hline 4 & $126-132$ & 18 & 129 & 20,93 & 56,98 \\
\hline 5 & $133-139$ & 15 & 136 & 17,44 & 74,42 \\
\hline 6 & $140-146$ & 13 & 143 & 15,12 & 89,53 \\
\hline 7 & $147-153$ & 9 & 150 & 10,47 & 100,00 \\
\hline Jumlah & $\mathbf{8 6}$ & & $\mathbf{1 0 0 , 0 0}$ & & \multicolumn{1}{|l}{} \\
\cline { 1 - 2 } & & & & &
\end{tabular}


Efektivitas Teknologi Pembelajaran dalam Menumbuhkan Minat Siswa Belajar Pendidikan Agama Islam (PAI)

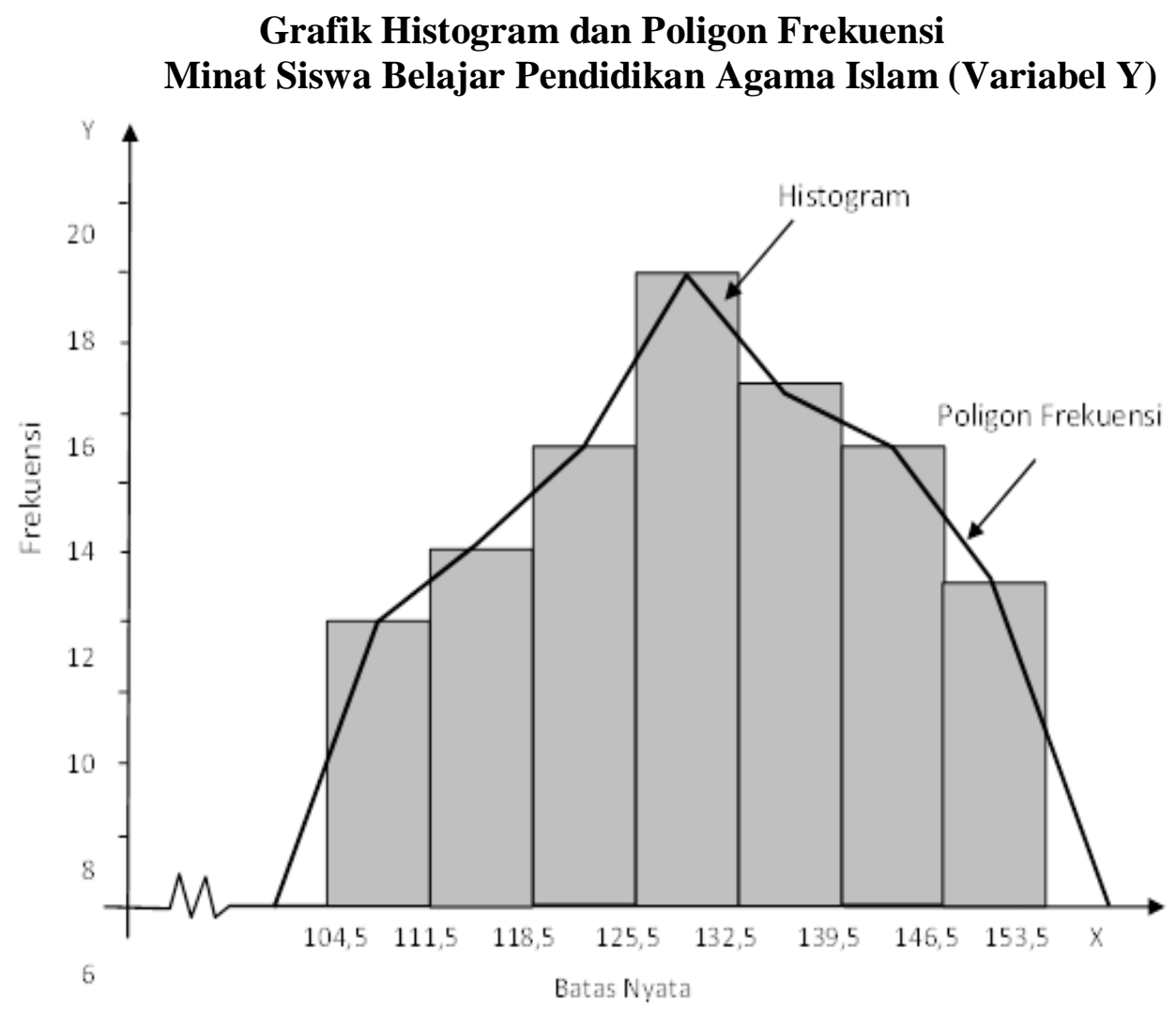

Klasifikasi Minat Siswa Belajar Pendidikan Agama Islam

\begin{tabular}{|c|c|c|c|c|}
\hline No & Interval Nilai & $\mathbf{f}$ & \% & Interpretasi \\
\hline 1 & $\mathrm{x}>142,33$ & 14 & 16,28 & Tinggi \\
\hline 2 & $117,46-142,33$ & 56 & 65,12 & Cukup \\
\hline 3 & $\mathrm{x}<117,46$ & 16 & 18,60 & Rendah \\
\hline
\end{tabular}

Berdasarkan tabel di atas, diperoleh informasi dan gambaran bahwa skor minat siswa belajar Pendidikan Agama Islam sebanyak 16,28\% yang memperoleh nilai tinggi, $65,12 \%$ memperoleh nilai cukup, dan 18,60\% memperoleh nilai rendah. 


\section{Rekapitulasi Hasil Uji Normalitas Efektivitas Teknologi Pembelajaran dan Minat Siswa Belajar Pendidikan Agama Islam}

\begin{tabular}{|c|c|c|c|c|}
\hline Variabel & $\mathbf{N}$ & $\mathbf{L}_{\text {hitung }}\left(\mathbf{L}_{\mathbf{0}}\right)$ & $L_{(0,05)(86)}$ & Simpulan \\
\hline $\mathbf{X}$ & $\mathbf{8 6}$ & $\mathbf{0 , 0 7 2}$ & $\mathbf{0 , 0 9 6}$ & $\begin{array}{c}\text { Data Berdistribusi } \\
\text { Normal }\end{array}$ \\
\hline $\mathbf{Y}$ & $\mathbf{8 6}$ & $\mathbf{0 , 0 4 8}$ & $\mathbf{0 , 0 9 6}$ & $\begin{array}{c}\text { Data Berdistribusi } \\
\text { Normal }\end{array}$ \\
\hline
\end{tabular}

Dari tabel hasil uji normalitas dapat diambil kesimpulan bahwa data variabel efektivitas teknologi pembelajaran dan minat siswa belajar Pendidikan Agama Islam berdistribusi normal.

\section{Uji Homogenitas}

$\mathrm{F}_{\text {hitung( 2,00) }}<\mathrm{F}_{\text {tabel }}(3,90)$, maka dapat disimpulkan bahwa kedua varians tersebut homogen.

Karena normalitas distribusi dan homogenitasnya telah terpenuhi, maka pengujian korelasional dengan product moment dapat dilakukan.

\section{Pengujian Hipotesis Penelitian}

Pengujian hipotesis dilakukan guna mengetahui terdapat atau tidaknya hubungan antara efektivitas teknologi pembelajaran dengan minat siswa belajar Pendidikan Agama Islam. Rumus yang digunakan yaitu korelasi Product Moment.

Berdasarkan tabel di atas, maka harga korelasi dapat dihitung dengan rumus: 
Efektivitas Teknologi Pembelajaran dalam Menumbuhkan Minat Siswa Belajar Pendidikan Agama Islam (PAI)

$$
\begin{aligned}
\mathrm{r} & =\frac{N \Sigma X Y-(\Sigma X)(\Sigma Y)}{\sqrt{\left.\left\{N \Sigma X^{2}-(\Sigma X)^{2}\right\} N \Sigma Y^{2}-(\Sigma Y)^{2}\right\}}} \\
& =\frac{86 \times 1195069-(9105)(11178)}{\sqrt{\left\{86 \times 990677-(9105)^{2}\right\}\left\{86 \times 1466098-(11178)^{2}\right\}}} \\
& =\frac{102775934-101775690}{\sqrt{\{85198222-82901025\}\{126084428-124947684\}}} \\
& =\frac{1000244}{\sqrt{2297197 \times 1136744}} \\
& =\frac{1000244}{1615959,438} \\
& =0,619
\end{aligned}
$$

Berdasarkan hasil tersebut bahwa harga korelasi 0,619 berada pada antara $r_{x y}=0,600-0,799$ yang berarti termasuk pada kategori tinggi, dengan demikian maka hubungan antara efektivitas teknologi pembelajaran dengan minat siswa belajar Pendidikan Agama Islam termasuk pada kategori tinggi.

Selanjutnya dilakukan perhitungan signifikansi koefisien korelasi dengan menggunakan uji $\mathrm{t}(t$-student) sebagai berikut:

$$
\begin{aligned}
& \mathrm{t}=\frac{r \sqrt{n-2}}{\sqrt{1-r^{2}}} \\
& \mathrm{t}=\frac{0,619 \sqrt{86-2}}{\sqrt{1-(0,619)^{2}}} \\
& \mathrm{t}=\frac{5,673}{0,785} \\
& \mathrm{t}=7,22
\end{aligned}
$$


Berdasarkan perhitungan tersebut bahwa pada taraf signifikansi 0,05 dan $\mathrm{dk}=84$, diperoleh $\mathrm{t}_{\text {hitung }}=7,22$ dan $t_{(0,975)(86)}=2,00$. Karena $\mathrm{t}_{\text {hitung }}=7,22>2,00=$ $t_{(0,975)(86)}$, maka kesimpulan yang dapat diambil adalah terdapat hubungan yang signifikan antara efektivitas teknologi pembelajaran dengan minat siswa belajar Pendidikan Agama Islam.

Untuk mengetahui besarnya pengaruh efektivitas teknologi pembelajaran siswa dengan minat siswa belajar Pendidikan Agama Islam, prosentase dihitung dengan koefisien determinasi (k.d) dengan rumus:

$$
\begin{aligned}
\mathrm{k} . \mathrm{d} & =\mathrm{r}^{2} \times 100 \% \\
& =(0,619)^{2} \times 100 \% \\
& =0,3831 \times 100 \% \\
& =38,31 \%
\end{aligned}
$$

Dari perhitungan di atas dapat diketahui bahwa pengaruh efektivitas teknologi pembelajaran terhadap minat siswa belajar Pendidikan Agama Islam sebesar $38,31 \%$ dan sisanya sebesar $61,69 \%$ dipengaruhi oleh faktor lain.

\section{Daftar Pustaka}

Al Qur'an dan Terjemahan Per kata Mushaf Lafziyyah Al Huda, Depok : Al Huda, 2009

A.M.,Sadirman, Interaksi dan Motivasi Belajar Mengajar, Jakarta : Rajawali, 1992

Arikunto, Suharsimi, Prosedur Penelitian Suatu Pendekatan Praktek, Jakarta: Rineka Cipta, 2006 
Efektivitas Teknologi Pembelajaran dalam Menumbuhkan Minat Siswa Belajar Pendidikan Agama Islam (PAI)

Arsyad, Azhar, Media pembelajaran, Jakarta:RajaGrafindo Persada, 2011

Az-Zhecolany, Ali Hasan, Kesalahan-Kesalahan Orang Tua Penyebab Anak Tidak Shalih, Jogjakarta: DIVA Press, 2011

Carlo, Mario, "Peranan dan Fungsi Minat Belajar" artikel $\begin{array}{lllll}\text { diakses } & \text { pada } & 2 & \text { September } & 2012 \\ \end{array}$ http//www.pinarac.wordpress.com

Dajan, Anto, Pengantar Metode Statistika jilid II, Jakarta : LP3ES, cetakan 11,1986

Dok. Kalbe Nutritionals. "Dicari, Karakter Anak Indonesia,” Kompas, 21 Juli 2011

Education, Business, Communication and Information. Artikel diakses di pada tanggal 20 Juli 2012 dari http://dansite.wordpress.com.

Ghuddah, Abdul Fattah Abu, 40 Metode Pendidikan dan penagajaran Rosulullah SAW, .Bandung: Irsyad Baitus Salam, 2009.

Hamalik, Oemar, Proses Belajar Mengajar, Jakarta: Bumi Aksara, 2011

Jihad, Asep, dan Haris, Abdul, Evaluasi Pembelajaran, Yogyakarta: Multi Pressindo, 2010

Kasmo, Sukasmo, "Efektivitas Pembelajaran" artikel di akses pada 10 November 2012 dari http://edukasi.kompasiana.com/2012/01/12/efektivitas-pembelajaran/.

Muhaimin, Paradigma Pendidikan Islam: Upaya Mengefektifkan Pendidikan Agama Islam di Sekolah, Bandung: Rosda Karya, 2004

Nasional, Departemen Pendidikan, Kamus Besar Bahasa Indonesia Pusat Bahasa edisi 4, Jakarta: Gramedia Pustaka Utama, 2008 
NC, Fatah Syukur, Teknologi Pendidikan. .Semarang : RaSAIL Media group. 2008.

Pidarta, Made, Landasan Kepenndidikan (Stimulus Ilmu Pendidikan Bercorak Indonesia), Jakarta: Rineka Cipta, 2009.

Pinarac. "Macam-macam Minat dan Faktor-faktor yang Mempengaruhi Minat Belajar" artikel diakses pada 2 Oktober 2012 dari $\mathrm{http} / / \mathrm{www}$.pinarac.wordpress.com

Ramayulis. Ilmu Pendidikan Islam, Jakarta : Kalam Mulia, 2002

RI, Departemen Agama, “ Pedoman Pengembangan Administrasi dan Supervisi Pendidikan”, Jakarta: Departemen Agama, 2004.

RI , Kementrian Agama, “UN / UAMBN / USBN Tahun 2012," $\begin{array}{lllll}\text { artikel dikses pada } 10 & \text { September } 2012\end{array}$ darihttp://mapendakukar.blogspot.com/p/pendataan-un.html.

Rizky, Asep Muhammad, "Profile SMP Negeri 4 Bekasi Menurut Wakil Kepala Sekolah," di akses pada tanggal $29 \quad$ November 012 di http://asepm.blogspot.com/2012/07/profile-sekolah-smpn-4-bekasimenurut_23.html

Sabri, H.M. Alisuf, Psikologi Pendidikan Berdasarkan Kurikulum Nasional. Jakarta : Pedoman Ilmu Jaya, 2010

Sadirman, Arief. S., et al. Media Pendidikan, Jakarta: Raja GrafindoPesada, 2005

Safrudin, "Analisis Hadist Tholabul 'Ilmi”" di akses pada tanggal 4 Desember 2012 pada http://rere-comp.blogspot.com/2011/02/analisis-haditstholabul-ilmi.html

Siti Masithoh, Nuning, Pengaruh Pengajaran Bidang Studi Al Qur'an dalam Menumbuhkan Minat Siswa Belajar al Qur'an (Studi Kasus pada Kelas I di SMK Yahta Syajar)," Skripsi SI Fakultas Tarbiyah, STIT al Marhalah al "Ulya, 2008 
Efektivitas Teknologi Pembelajaran dalam Menumbuhkan Minat Siswa Belajar Pendidikan Agama Islam (PAI)

Slameto, Belajar dan Faktor-Faktor yang Mempengaruhinya, Jakarta: Rineka Cipta, 2010

SMK Darunnajah "Macam-macam Media Pembelajaran, Karakteristik serta kelebihan dan kekurangannya. "' Di akses pada tanggal 20 September 2012 di http://www..sch.id/2011/11/macam-macam-mediapembelajaran.html.

SMPN 4 Bekasi "Selayang Pandang SMP Negeri 4 Bekasi," di akses pada tanggal 29 November 2012 di http://smpn4kotabekasi.blogspot.com/

Sudjana, Metoda Statistika, Bandung: Tarsito, 2005

Sugiyono, Metode Penelitian Pendidikan (Pendekatan Kuantitatif, Kualitatif, dan R\&D). Bandung: Alfabeta, 2010

-, Statiska untuk Penelitian, Bandung : Alfabeta, 2010

Sumiati dan Asra, Metode Pembelajaran. Bandung: Wacana Prima, 2009.

Surya, Muhammad, Karakteristik dalam Proses Belajar Mengajar, Bandung: Media Pembinaan, 2000

Syah, Muhibbin, Psikologi Belajar, Jakarta : RajaGrafindo Persada, 2012

Syarbini, Amirulloh dan Khusaeri, Akhmad, kiat-kiat Islami Mendidik Akhlak Remaja, Jakarta: Elex Media Komputindo, 2012

"Tabel 3.1 Kisi-Kisi Instrumen untuk Pengaruh Efektivitas Penggunaan dan Kepercayaan atas Teknologi Sistem Informasi Akuntasi Terhadap Kinerja Auditor Internal," artikel di akses pada 26 November 2012 dari http://www.scribd.com/doc/45267077/39/Tabel-3-1-Kisi-kisiInstrumen-Penelitian

Warsita, Bambang, Teknologi Pembelajaran Landasan dan Aplikasinya, Jakarta: Renika Cipta, 2008. 
Eva Dwi Kumala Sari

Wicaksono, Ady, "Pembangunan Aplikasi Penjualan Online pada CV. Fanan Jaya Berbasis WEB."(Skripsi S1 Jurusan Teknik Informatika, Fakultas teknik dan Ilmu Komputer, Universitas Komputer Indonesia, 2011

Al Marhalah : Jurnal Pendidikan Islam. Volume. 1, No.2 November 2017 